\title{
Incidence and contamination level of Clostridium perfringens in meat and meat products sold in Sakarya province of Turkey
}

\author{
Serap COŞANSU, Şeyma Şeniz ERSÖZ
}

Cite this article as:

Coşansu, S., Ersöz, Ş.Ş. (2021). Incidence and contamination level of Clostridium perferingens in meat and meat products sold in Sakarya province of Turkey. Food and Health, 7(3), 172-178. https://doi.org/10.3153/FH21018

Food Engineering Department, Engineering Faculty, Sakarya University, 54187, Sakarya, Turkey

ORCID IDs of the authors:

S.C. 0000-0003-2875-1335

Ş.Ş.E. 0000-0001-7481-1170

Submitted: 12.06 .2020

Revision requested: 02.11 .2020

Last revision received: 11.12 .2020

Accepted: 25.12 .2020

Published online: 06.04.2021

Correspondence:

Serap COŞANSU

E-mail: scosansu@sakarya.edu.tr

\begin{abstract}
Totally 101 meat and meat product samples obtained from local markets and restaurants were analyzed for incidence and contamination level of Clostridium perfringens. The typical colonies grown anaerobically on Tryptose Sulfite Cycloserine Agar supplemented with 4-Methyliumbelliferyl (MUP) were confirmed by biochemical tests. Forty-eight of the samples $(47.5 \%)$ were contaminated with $C$. perfringens. The highest incidence of the pathogen was determined in uncooked meatball samples $(72.2 \%)$ followed by ground beef samples $(61.3 \%)$. The incidence of $C$. perfringens in chicken meat, cooked meat döner, cooked chicken döner and emulsified meat product samples were 33.3, 33.3, 28.6 and $16.7 \%$, respectively. Thirteen out of 101 samples (12.9\%) yielded typical colonies on TSC-MUP Agar, but could not be confirmed as C. perfringens. Average contamination levels in sample groups ranged from 8.3 to $1.5 \times 10^{2} \mathrm{cfu} / \mathrm{g}$, with the highest ground beef and the lowest chicken meat.
\end{abstract}

Keywords: Clostridium perfringens, Incidence, Meat, Meat products, Ground beef, Meatball

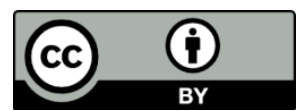

(C) 2021 The Author(s)

Available online at

http://jfhs.scientificwebjournals.com 


\section{Introduction}

Clostridium perfringens is an anaerobic, non-motile, sulfite reducing, spore-forming, Gram-positive and rod-shaped bacterium (Brynestad and Granum, 2002; Garcia et al., 2019). Spores are usually located sub-terminally and formed only in specially formulated culture media (Juneja et al., 2010). It was isolated in 1892 and named as Bacillus aerogenes and then as Clostridium welchii (Garcia and Heredia, 2011). It can grow at temperatures from $15^{\circ} \mathrm{C}$ to $50^{\circ} \mathrm{C}$ with an optimum at $45^{\circ} \mathrm{C}$ for most strains (Brynestad and Granum, 2002). $C$. perfringens is very common in nature and can be isolated from soil, dust, gastrointestinal systems of human and animals, on surfaces of vegetables as well as other raw and processed foods (Juneja et al., 2010). Although it has an anaerobic nature, it can grow at $\mathrm{E}_{\mathrm{h}}$ values of $+350 \mathrm{mV}$ and can reduce its environment to less than $-400 \mathrm{mV}$ (Garcia and Heredia, 2011).

Acute diarrhea and severe abdominal pain are observed in 8$24 \mathrm{~h}$ following the digestion of the food harbored high number vegetative cells of $C$. perfringens. Vomiting and fever are very rare. Generally the patient recovers in $24-48 \mathrm{~h}$. Death is rare and particularly seen in elderly patients (Labbe and Juneja, 2017). C. perfringens is classified as A, B, C, D and $\mathrm{E}$ according to toxin type. The type $\mathrm{A}$ is related food poisoning, meanwhile can cause gaseous gangrene and septicemia (Brown, 2000; McClane et al., 2012). In the European Union, C. pefringens caused 124 out of 160 total outbreaks occurred in 2014 (EFSA-ECDC, 2015). It is estimated that $C$. perfringens poisoning is more common since the mild cases are not reported (Juneja et al., 2010). Considering the relatively mild symptoms, the under-reported cases have been estimated as 10-fold (Mead et al., 1999). Foodborne poisoning associated with $C$. perfringens is due to improper handling and preparation of foods. A recent report revealed that improper stored and inadequate reheated meat could result in large C. perfringens outbreak (Mellou et al. 2019). The high number of vegetative cells $\left(>10^{6} \mathrm{cfu} / \mathrm{g}\right)$ multiplied in food exposed to elevated temperatures are ingested and then food poisoning occurs (Garcia and Heredia, 2011).

C. perfringens contaminated meat and meat products via fecal contamination of carcasses or contamination from other ingredients such as spices, post-processing contamination is possible as well (Juneja et al., 2010; McClane et al., 2012; EFSA-ECDC, 2015). Although C. perfringens can be isolated from different types of foods, it is mostly isolated from meat and meat products. Because meat and meat products are good sources of thirteen amino acids which cannot be produced by $C$. perfringens and needed for growth of this pathogen (Andersson et al., 1995). The previous studies have shown than C. perfringens incidence ranged from 7 to $96 \%$ in meat and meat products including ground beef (Başkaya et al., 2004; Kamber et al., 2007), chicken meat (Çakmak et al., 2006; Y1ldırım et al., 2015), beef and sheep meats (Guran et al., 2014), cured raw meat products (Taormina et al., 2003), emulsified meat products (Elmalı et al., 2005) and cooked döner (Vazgecer et al., 2004). As far as we have known there is not any survey study in the literature on incidence of $C$. perfringens in meat and meat products sold in Sakarya, Turkey. Therefore, considering the survey studies may provide a better understanding the risk for foodborne pathogens, it was aimed in this study to determine the incidence and contamination level of $C$. perfringens in meat and meat products sold in Sakarya province of Turkey.

\section{Materials and Methods}

\section{Materials}

Totally 101 samples including ground beef (31), chicken meat (27), meatball (18), cooked meat döner (12), cooked chicken döner (7) and emulsified meat products (6) were collected from 57 different butcher shops, markets and fast food restaurants between April 2013 and February 2014 in Sakarya province of Turkey. Samples were transferred to laboratory in cooled conditions and kept in refrigerator until analysis.

\section{Preparation of Samples for Analyses and C. perfringens Enumeration}

C. perfringens enumeration and confirmation was performed according to the method described by Rhodehamel and Harmon (1998). Aseptically $25 \mathrm{~g}$ sample was transferred into a stomacher bag with $225 \mathrm{~mL}$ sterile peptone water (1\% peptone) and homogenized (BagMixer ${ }^{\circledR}$ 400, Interscience Co., Saint Nom, France) for two minutes at low speed. Serial dilutions were prepared using peptone water. The pour plating technique was used for enumeration of $C$. perfringens. One $\mathrm{mL}$-portions from $10^{-1}$ and $10^{-2}$ dilutions were transferred to sterile petri plates and Tryptose Sulfite Cycloserine (TSC) Agar (Merck, Darmstadt, Germany) containing MUP (4Methylumbelliferyl phosphate) was poured and mixed well. After solidifying, the plates were overlaid with an additional $10 \mathrm{~mL}$ TSC Agar. The plates were incubated anaerobically (Anaerocult A; Merck, Darmstadt, Germany) at $37^{\circ} \mathrm{C}$ for 24 h. Following incubation plates were examined under $366 \mathrm{~nm}$ ultraviolet light (366 nm UV Lamp; Merck Darmstadt, Germany) and the black colonies with blue florescence were counted as $C$. perfringens. 


\section{Morphological and Biochemical Confirmation}

The typical colonies grown on TSC Agar were picked and inoculated in Thioglycolate Broth (Merck, Darmstadt, Germany). Tubes were incubated anaerobically at $37^{\circ} \mathrm{C}$ for $24 \mathrm{~h}$. The Thioglycolate Broth cultures of the isolates were maintained at $-20^{\circ} \mathrm{C}$ by adding $15 \%$ glycerol. Gram-positive and sporeforming isolates were subjected to biochemical tests. $C$. perfringens was confirmed by motility-nitrate and lactosegelatin tests (Anonymous, 1999). The active cultures of suspected isolates were stab-inoculated into Motility-Nitrate Medium (Sigma-Aldrich, St. Louis, MO, USA) and incubated anaerobically at $37^{\circ} \mathrm{C}$ for $24 \mathrm{~h}$. The cultures grown only along the stab line in Motility-Nitrate Medium were considered non-motile, while those grown away from the stab line were considered motile. Red color formation after addition of nitrite-detection reagent (Sigma-Aldrich, St. Louis, MO, USA) showed the reduction of nitrate. If no red color observed within $15 \mathrm{~min}$, zinc dust was added and color of the medium was checked after $10 \mathrm{~min}$. The Lactose-Gelatin Medium (Sigma-Aldrich, St. Louis, MO, USA) tubes inoculated with active cultures were incubated anaerobically at $37^{\circ} \mathrm{C}$ for $24 \mathrm{~h}$. The gas blisters and converting the color from red to yellow were the signs of lactose fermentation. To detect gelatinase activity, the tubes were kept at $5^{\circ} \mathrm{C}$ for $1 \mathrm{~h}$ and checked for liquefaction. In case solidification occurred, the tubes were incubated at $37^{\circ} \mathrm{C}$ for additional $24 \mathrm{~h}$. The cultures in liquefied tubes were considered gelatinase positive.

\section{Results and Discussion}

Totally 101 samples, including ground beef, chicken meat, uncooked meatball, cooked meat döner, cooked chicken döner and emulsified meat products, were analyzed for incidence and contamination level of $C$. perfringens. Table 1 depicts incidence of the pathogen in the samples. Out of 101 samples, $48(47.5 \%)$ were positive for $C$. perfringens. Although thirteen samples (4 ground beef, 3 uncooked meatballs, 3 chicken meat, and one emulsified meat product) yielded typical colonies on TSC Agar, these colonies could not be confirmed as $C$. perfringens by biochemical tests. This result is not surprising considering the specificity of the culture medium used in this study. Fischer at al. (2012) have mentioned that the specificity of TSC-MUP Agar was 74.5\%. In other words this culture medium yielded $24.5 \%$ false negative results and non-perfringens Clostridium species were isolated frequently. The highest incidence of the pathogen was in uncooked meatball samples $(72.2 \%)$ followed by ground beef samples $(61.3 \%)$. The previous studies have shown that incidence of $C$. perfringens and/or sulfite reducing bacteria in beef meat or ground beef is ranged from 18 to $96 \%$. C. perfringens incidence was reported as $18 \%$ in ground beef samples sold in small butcher shops and local markets (Kamber et al., 2007). Başkaya et al. (2004) determined sulfite reducing anaerobic bacteria in $74 \%$ of the ground beef samples. Guran et al. (2014) reported that $96 \%$ of beef meat samples were contaminated with $C$. perfringens.

The incidence of the pathogen was $72.2 \%$ in meatball samples. Meatball is produced mainly from ground beef and/or lamb meat, fat, roasted bread crumbs, salt, onion garlic and various spices. The spices used to prepare meatball may increase the microbial load of product. De Boer et al. (1985) isolated $C$. perfringens spores from $80 \%$ of 54 spices and herbs. It is well known that spices are main source of sporeforming pathogenic bacteria including Bacillus and Clostridium species and under favorable conditions their spores may germinate and multiply (Pafumi, 1986). Therefore, the spices used in meatball recipe may be the reason for high incidence of $C$. perfringens in meatball samples.

Table 1. C. perfringens incidence in meat and meat products

\begin{tabular}{lcccc}
\hline Sample type & $\begin{array}{c}\text { Sample } \\
\text { number }\end{array}$ & $\begin{array}{c}\text { C. perfringens confirmed } \\
\text { sample number (\%) }\end{array}$ & $\begin{array}{c}\text { Sample number with typi- } \\
\text { cal colony on TSC Agar } \\
\text { but not confirmed (\%) }\end{array}$ & $\begin{array}{c}\text { Sample number with } \\
\text { no typical colony on } \\
\text { TSC Agar (\%) }\end{array}$ \\
\hline Ground beef & 31 & $19(61.3)$ & $4(12.9)$ & $8(25.8)$ \\
Meatball (uncooked) & 18 & $13(72.2)$ & $3(16.2)$ & $2(11.1)$ \\
Chicken meat & 27 & $9(33.3)$ & $5(18.5)$ & $13(48.2)$ \\
Meat döner (cooked) & 12 & $4(33.3)$ & $0(0)$ & $8(66.7)$ \\
Chicken döner (cooked) & 7 & $2(28.6)$ & $0(0)$ & $5(71.4)$ \\
Emulsified meat products & 6 & $1(16.7)$ & $1(16.7)$ & $4(66.6)$ \\
\hline Total & 101 & $48(47.5)$ & $13(12.9)$ & $40(39.6)$ \\
\hline
\end{tabular}


C. perfringens incidence was confirmed only in 9 chicken meat samples $(33.3 \%)$. The previous studies have shown that the incidence of this pathogen in poultry products may vary from 2.5 to $94 \%$ according to product type. Çakmak et al. (2006) detected C. perfringens in 70\% of frozen raw ground poultry samples while $2.5 \%$ of poultry burger samples were contaminated with this pathogen. Yildirım et al. (2015) reported that $46 \%$ of chicken leg and breast meat samples were positive for C. perfringens. Shaltout et al. (2017) determined $C$. perfringens in $21.6 \%$ of chicken meats samples. Higher incidence levels were reported by Guran and Oksuztepe (2013). These researchers determined that $66-94 \%$ of chicken parts were contaminated with $C$. perfringens. Incidence of this pathogen in intestinal tract of broiler chickens can be as high as $95 \%$ (Immerseel et al., 2004). Therefore it is not unexpected situation that its incidence in processed meat of poultry is high.

The incidence of $C$. perfringens in cooked beef and chicken döner samples were 33.3 and $28.6 \%$, respectively. The previous studies revealed that the incidence of sulfite reducing Clostridia incidence is low in döner samples. Vazgecer et al. (2004) reported that sulfite reducing Clostridia were determined in the $7 \%$ of the cooked döner samples. In contrast, Bostan et al. (2011) did not determined sulfite reducing Clostridia in cooked döner samples. Spores of $C$. perfringens may survive during cooking and then if cooked foods are kept at temperatures between $12^{\circ} \mathrm{C}$ and $50^{\circ} \mathrm{C}$ they can germinate and multiply. Moreover an efficient reheating step may be required to kill vegetative cells (Jaloustre et al, 2013). Döner is a very popular meat meal which is prepared by seasoning of meat with spices and then cooking of cone-like shaped meat mass in front of cooking apparatus. Meat mass is rotated slowly during cooking and the cooked surface layer is cut as thin flakes. In this cooking process, the temperature of meat mass may be at ranges that allow survival and growth of spore-forming bacteria including pathogenic species. Considering cooking method, döner may have risk for $C$. perfringens.

C. perfringens was confirmed only in one emulsified meat product sample (16.7\%). Apaydin et al. (2003) reported that $10 \%$ of bologna-type sausage samples were contaminated with $C$. perfringens. The incidence of the pathogen in emulsified meat products was determined as $22.1 \%$ by Elmalı et al. (2005). The spores of $C$. perfringens are heat resistant with 34.2 min D value at $90^{\circ} \mathrm{C}$ (Byrne et al., 2006). With this in mind, it can be estimated that they can well survive during production of this type of meat products.

The differences between the isolation rates of the current study and the previous ones may be attributed to number of the samples and analysis methods. The method used in this study did not contain any enrichment step. Wen and McClane (2004) reported approximately 50 -fold increase in $C$. perfringens recovery when an enrichment procedure is applied using Fluid Thioglycolate medium.

Fluorogenic substrate, 4-methylumbelliferyl phosphate (MUP), added TSC Agar was used in this study for enumeration and isolation of $C$. perfringens from the meat products. MUP is a fluorogenic substrate which is highly specific for $C$. perfringens. MUP is metabolized by $C$. perfringens producing 4-methylumbelliferone which can be detected under a long wave (366 nm) UV light (Adcock and Paint, 2001). Thirteen out of 101 samples yielded typical colonies on TSC Agar supplemented with MUP. That is to say, false-positive result ratio was $12.9 \%$. Similarly, Araujo et al. (2001) reported false-positive results on this culture medium during recovery of $C$. perfringens from groundwater samples. Despite this, the researchers found that the MUP added TSC Agar was superior to the other culture media used for detection of $C$. perfringens.

The contamination levels in the $C$. perfringens confirmed samples are shown in Table 2. Results revealed that $41.6 \%$ of the samples harbored $C$. perfringens lower than $10^{1} \mathrm{cfu} / \mathrm{g}$. More than half of the confirmed samples $(52.1 \%)$ contained the pathogen in the range from $10^{1}$ to $10^{2} \mathrm{cfu} / \mathrm{g}$. The contamination level of the pathogen was $10^{2}-10^{3} \mathrm{cfu} / \mathrm{g}$ only in two meatball samples. The highest level detected in one ground beef sample was $2.4 \times 10^{3} \mathrm{cfu} / \mathrm{g}$. The average counts of sample groups were ranged from 8.3 to $1.5 \times 10^{2} \mathrm{cfu} / \mathrm{g}$. According to Turkish Food Codex Regulation on Microbiological Criteria (Anonymous, 2011), the counts of sulphite reducing anaerobic bacteria should not exceed $10^{4}$ and $10^{3} \mathrm{cfu} / \mathrm{g}$ in non-readyto-eat and ready-to-eat foods, respectively. Based on this knowledge, it can be concluded that the samples analyzed in current study had acceptable levels of $C$. perfringens as a member of sulphite reducing anaerobic bacteria group. On the other hand, these results are generally in consistent with the published data. Kamber et al. (2007) determined levels of $C$. perfringens in ground beef samples obtained from local markets and butcher's shops as $2.75 \times 10^{2}$ and $6.82 \times 10^{2} \mathrm{cfu} / \mathrm{g}$, respectively. Apaydin et al. (2003) reported the incidence of C. perfringens as 1-1.27 log cfu/g in bologna-style sausages. The mean number of ground poultry samples was determined as $2.6 \mathrm{MPN} / \mathrm{g}$ by Çakmak et al. (2006). On the other hand, Y1ldirım et al. (2015) have stated that the mean counts of $C$. perfringens in chicken breast and leg meats were $3.21 \times 10^{3}$ and $1.64 \times 10^{4} \mathrm{cfu} / \mathrm{g}$, respectively. These levels are higher than both our study and the previous studies. 
Table 2. Contamination levels in C. perfringens confirmed samples

\begin{tabular}{lccccc}
\hline \multirow{2}{*}{ Sample type } & \multicolumn{2}{c}{ Number of samples for each contamination level } & $\begin{array}{c}\text { Average } \\
\text { (cfu/g) }\end{array}$ \\
\hline Ground beef & $<10^{1}$ & $10^{1}-10^{2}$ & $10^{2}-10^{3}$ & $>10^{3}$ & $\begin{array}{c}\text { (cfure } \\
\text { Chicken meat }\end{array}$ \\
Meatball (uncooked) & 7 & 12 & 0 & 0 & $1.5 \times 10^{2}$ \\
Meat döner (cooked) & 5 & 2 & 0 & 0 & $5.8 \times 10^{1}$ \\
Chicken döner (cooked) & 2 & 6 & 2 & 0 & $2.3 \times 10^{1}$ \\
Heat processed meat products & 0 & 2 & 0 & 0 & $2 \times 10^{1}$ \\
\hline Total & 0 & 2 & 0 & 0 & $1.5 \times 10^{1}$ \\
\hline
\end{tabular}

C. perfringens vegetative cells higher than $10^{6}$ cfu per gram of food are needed to result in food poisoning (Juneja et al., 2010). The numbers of the pathogen in the samples analyzed did not exceed this level. However, to control temperature during cooking and storage is a key factor to avoid $C$. perfringens poisoning. If the cooked food is cooled down slowly, kept at warm temperatures for extended periods and not reheated sufficiently before consumption to destroy vegetative cells, this critical level may be reached. Additionally, cooking may provide more favorable conditions for the growth of $C$. perfringens by increasing anaerobic environment and reducing competing spoilage organisms (Juneja et al., 2010; Kouassi et al. 2014). Moreover, cooking may cause heat shock which triggers the germination of spores (Juneja et al., 2010).

\section{Conclusion}

It may be concluded that $C$. perfringens is very common in raw or cooked meat products having regard to its confirmed presence in almost half of samples (47.5\%) analyzed in this study. The highest incidence was in uncooked meatball samples followed by ground beef samples. Although the contamination levels in samples analyzed in this study were lower than that of required for food poisoning $\left(10^{6} \mathrm{cfu} / \mathrm{g}\right)$, it seems that presence of this pathogen in meat and meat products is generally unavoidable. All things considered, it should be emphasized that temperature control during processing, transportation and storage is the key factor for prevention growth of $C$. perfringens and thus food poisoning caused by this pathogen. Another key thing to remember is that the temperature and time during cooking and/or reheating should be adequate to kill vegetative cells of $C$. perfringens.

\section{Compliance with Ethical Standard}

Conflict of interests: The authors declare that for this article they have no actual, potential or perceived the conflict of interests.

Ethics committee approval: Author declare that this study does not include any experiments with human or animal subjects.

Funding disclosure: Financial support was provided by Commission of Scientific Research Projects of Sakarya University (Project Number: BAP-2012-01-16-009)

Acknowledgments: -

Disclosure: -

\section{References}

Adcock, P.W., Saint, C.P. (2001). Rapid confirmation of Clostridium perfringens by using chromogenic and fluorogenic substrates. Applied Environmental Microbiology, 67(9), 4382-4384.

https://doi.org/10.1128/AEM.67.9.4382-4384.2001

Andersson, A., Ronner, U., Granum, P.E. (1995). What problems does the food industry have with the spore-forming pathogens Bacillus cereus and Clostridium perfringens? International Journal of Food Microbiology, 28, 145-155. https://doi.org/10.1016/0168-1605(95)00053-4

Anonymous (1999). Microbiology of food and animal feeding stuffs-Horizontal method for the enumeration of Clostridium perfringens. Colonies count technique (ISO 7937: 1997 Modified). European Standard (EN 13401).

Anonymous (2011). Türk Gida Kodeksi Mikrobiyolojik Kriterler Yönetmeliği Retrieved from https://www.resmigazete.gov.tr/eskiler/2011/12/20111229M 3-6.htm (Accessed 01.06.2020). 
Apaydin, G., Ceylan, Z.G., Kaya, M. (2003). Değişik firmalara ait salamların bazı mikrobiyolojik ve kimyasal özellikleri. Turkish Journal of Veterinary and Animal Science, 27, 1299-1303.

Araujo, M., Sueiro, R.A., Gómez, M.J., Garrido, M.J. (2001). Evaluation of fluorogenic TSC agar for recovering Clostridium perfringens in groundwater samples. Water Science and Technology, 43(12), 201-204.

https://doi.org/10.2166/wst.2001.0738

Başkaya, R., Karaca, T., Sevinç, İ., Çakmak, Ö., Yildiz, A., Yörük, M. (2004). İstanbul'da Satışa Sunulan Hazır Kıymaların Histolojik, Mikrobiyolojik ve Serolojik Kalitesi. Yüzüncü Yll Üniversitesi Veteriner Fakültesi Dergisi, 15(1), 41-46.

Bostan, K., Yılmaz, F., Muratoğlu, K., Aydın, A. (2011). Pişmiş döner kebaplarda mikrobiyolojik kalite ve mikrobiyel gelişim üzerine bir araştırma. Kafkas Üniversitesi Veteriner Fakültesi Dergisi, 17(5), 781-786.

https://doi.org/10.9775/kvfd.2011.4438

Brown, K.L. (2000). Control of bacterial spores. British Medical Bulletin, 56 (1), 158-171.

https://doi.org/10.1258/0007142001902860

Brynestad, S., Granum, P.E. (2002). Clostridium perfringens and foodborne infections. International Journal of Food Microbiology, 74(3), 195-202.

https://doi.org/10.1016/S0168-1605(01)00680-8

Byrne, B., Dunne, G., Bolton, D.J. (2006). Thermal inactivation of Bacillus cereus and Clostridium perfringens vegetative cells and spores in pork luncheon roll. Food Microbiology, 23(8), 803-808.

https://doi.org/10.1016/j.fm.2006.02.002

Çakmak, Ö., Ormancı, F.S.B., Tayfur, M., Erol, İ. (2006). Presence and contamination level of Clostridium perfringens in raw frozen ground poultry and poultry burgers. Turkish Journal of Veterinary and Animal Sciences, 30(1), 101-105.

De Boer, E., Spiegelenberg, W.M., Janssen, F.W. (1985). Microbiology of spices and herbs. Antonie van Leeuwenhoek, 51(4), 435-438.

https://doi.org/10.1007/BF02275058

EFSA-ECDC (European Food Safety Authority-European Centre for Disease Prevention and Control), (2015). The European Union summary report on trends and sources of zoonoses, zoonotic agents, and food-borne outbreaks in 2014. EFSA Journal, 13(4329), 191.

https://doi.org/10.2903/j.efsa.2015.4329

EImalı, M., Ulukanlı, Z., Yaman, H. (2005). Microbiological quality of emulsified type meat products (salami-frankfurter sausage) marketed in Kars. Journal of Faculty of Veterinary Medicine, Erciyes University, 2(1), 15-21.

Fischer, M., Zhu, S., de Ree, E. (2012). Culture media for the detection and enumeration of clostridia in food. In: Handbook of Culture Media for Food and Water Microbiology, J.E.L Corry, G.D.W. Curtis, R.M. Baird (Eds.), Royal Society of Chemistry Publishing, p. 66-89.

https://doi.org/10.1039/9781847551450-00066

Garcia, S., Heredia, N. (2011). Clostridium perfringens: a dynamic foodborne pathogen. Food and Bioprocess Technology, 4(4), 624-630.

https://doi.org/10.1007/s11947-009-0182-2

García, S., Vidal, J.E., Heredia, N., Juneja, V.K. (2019). Clostridium perfringens. In: Food Microbiology: Fundamentals And Frontiers, Michael P. Doyle, Francisco Diez-Gonzalez, Colin Hill (Editors), 5th Edition, ASM Books, pp. 513540.

https://doi.org/10.1128/9781555819972.ch19

Guran, H.S., Oksuztepe, G. (2013). Detection and typing of Clostridium perfringens from retail chicken meat parts. Letters in Applied Microbiology, 57(1), 77-82.

https://doi.org/10.1111/lam.12088

Guran, H.S., Vural, A., Erkan, M.E. (2014). The prevalence and molecular typing of Clostridium perfringens in ground beef and sheep meats. Journal für Verbraucherschutz und Lebensmittelsicherheit, 9(2), 121-128.

https://doi.org/10.1007/s00003-014-0866-Z

Immerseel, F.V., Buck, J.D., Pasmans, F., Huyghebaert, G., Haesebrouck, F., Ducatelle, R. (2004). Clostridium perfringens in poultry: an emerging threat for animal and public health. Avian pathology, 33(6), 537-549.

https://doi.org/10.1080/03079450400013162

Jaloustre, S., Guillier, L., Poumeyrol, G., Morelli, E., Delignette-Muller, M.L. (2013). Efficiency of a reheating step to inactivate Clostridium perfringens vegetative cells: How to measure it? Food Control, 29(2), 422-428.

https://doi.org/10.1016/j.foodcont.2012.07.003 
Juneja, V.K., Novak, J.S., Labbe, R.J. (2010). Clostridium perfringens. In: Pathogens and Toxins in Foods: Challenges and Interventions, V.K. Juneja, J.N. Sofos (Eds.), ASM Press, Washington DC, USA. p. 53-70.

https://doi.org/10.1128/9781555815936.ch4

Kamber, U., Gokce, H.I., Elmalı, M. (2007). Clostridium perfringens and its toxins in minced meat from Kars, Turkey. Food Additives and Contaminants, 24(7), 673-678.

https://doi.org/10.1080/02652030601186129

Kouassi, K.A., Dadie, A.T., N'Guessan, K.F., Dje, K.M., Loukou, Y.G. (2014). Clostridium perfringens and Clostridium difficile in cooked beef sold in Cote d'Ivoire and their antimicrobial susceptibility. Anaerobe, 28, 90-94.

https://doi.org/10.1016/j.anaerobe.2014.05.012

Labbe, R.G., Juneja, V.K. (2017). Clostridium perfringens. In Foodborne Diseases (pp. 235-242). Academic Press. https://doi.org/10.1016/B978-0-12-385007-2.00010-3

McClane, B.A., Robertson, S.L., Li, J. (2012). Clostridium perfringens. In: Food Microbiology: Fundamentals and Frontiers, M.P. Doyle, R.L. Buchanan (Eds.), American Society for Microbiology Press, p.465-489.

https://doi.org/10.1128/9781555818463.ch18

Mead, P.S., Slutsker, L., Dietz, V., McCaig, L.F., Bresee, J.S., Shapiro, C., Griffin, P.M., Tauxe, R.V. (1999). Foodrelated illness and death in the United States. Emerging Infectious Diseases, 5, 607-625.

https://doi.org/10.3201/eid0505.990502

Mellou, K., Kyritsi, M., Chrysostomou, A., Sideroglou, T., Georgakopoulou, T., Hadjichristodoulou, C. (2019). Clostridium perfringens foodborne outbreak during an athletic event in Northern Greece, June 2019. International Journal of Environmental Research and Public Health, 16(20), 3967. https://doi.org/10.3390/ijerph16203967
Pafumi, J. (1986). Assessment of the microbiological quality of spices and herbs. Journal of Food Protection, 49(12), 958963.

https://doi.org/10.4315/0362-028X-49.12.958

Rhodehamel, J., Harmon, S. (1998). Clostridium perfringens, Bacteriological Analytical Manual, 8th Edition, Revision A, Chapter 16.

Shaltout, F.A., Osman, I.M., Kamel, E.A., Abd-Alla, A.K. (2017). Isolation of Clostridium perfringens from Meat Samples Obtained from the University Students' Hostel. EC Nutrition, 9(3), 142-150.

Taormina, P.J., Bartholomew, G.W., Dorsa, W.J. (2003). Incidence of Clostridium perfringens in commercially produced cured raw meat product mixtures and behavior in cooked products during chilling and refrigerated storage. Journal of Food Protection, 66(1), 72-81.

https://doi.org/10.4315/0362-028X-66.1.72

Vazgecer, B., Ulu, H., Oztan, A. (2004). Microbiological and chemical qualities of chicken döner kebab retailed on the Turkish restaurants. Food Control, 15(4), 261-264.

https://doi.org/10.1016/S0956-7135(03)00065-3

Wen, Q., McClane, B.A. (2004). Detection of enterotoxigenic Clostridium perfringens type A isolates in American retail foods. Applied and Environmental Microbiology, 70(5), 2685-2691.

https://doi.org/10.1128/AEM.70.5.2685-2691.2004

Yıldırım, Z., Ceylan, Ş., Öncül, N. (2015). Tokat piyasasında satışa sunulan tavuk etlerinin mikrobiyolojik kalitesinin belirlenmesi. Akademik Glda, 13(4), 304-316. 